Journal of Applied Sciences, 2009

ISSN 1812-5654

(C) 2009 Asian Network for Scientific Information

\title{
Adoption of Internet Banking by Iranian Consumers: An Empirical Investigation
}

\author{
${ }^{1,2}$ Arezou Pour Mirza, ${ }^{3}$ Mohammad T. Hamidi Beheshti, ${ }^{2} \AA$ sa Wallström and ${ }^{4}$ Omid Pour Mirza \\ ${ }^{1}$ Department of Industrial Engineering, Tarbiat Modares University, Tehran, Iran \\ ${ }^{2}$ Department of Business Administration and Social Sciences, Luleå University of Technology, Luleå, Sweden \\ ${ }^{3}$ Department of Electrical and Computer Engineering, Tarbiat Modares University, Tehran, Iran \\ ${ }^{4}$ Faculty of Management, Multimedia University, Kuala Lumpur, Malaysia
}

\begin{abstract}
This study was conducted to develop an understanding of Iranian customer's attitude and adoption of Internet banking services. Through using data from a questionnaire survey; demographic, attitudinal and behavioral characteristics of Internet banking users and non-users of Mellat bank customers from governmental sector are examined. The results revealed significant differences between demographic profiles and attitudes of users and non-users groups. The majority of the customers are very comfortable and willing to use Internet banking services. Branch counter was the most frequently adopted channel. The security concerns, lack of technological knowledge and awareness stand out as being obstacles to the adoption of Internet banking services. The present study provides a set of factors that are perceived to have impact on Internet banking adoption, baseline data for further research and an updated account of the Internet banking behaviors of Iranian customers.
\end{abstract}

Key words: E-commerce, behavior, security, transaction

\section{INTRODUCTION}

Service sectors have witnessed a rapid shift particularly in the last decade under the pressure of technology, which is creating new products, services, market opportunities and developing more information and system-oriented business and management processes (Liao and Cheung, 2002). In the world of banking; the developments in information technology have had an enormous effect in development of more flexible payment methods and more efficient banking services. This technology offers institutions some efficient delivery channels through which customer banking requirement can be delivered more conveniently and economically (Akinçi et al., 2004; Brodie et al., 2007; David et al., 2008). One of the delivery channels introduced for financial services is Internet Banking (IB) or online-banking. To use Internet based financial services, consumers not only need to understand the technology they also need to understand financial services. It is well accepted that IB is a useful tool in banking system that offers less waiting time and is more convenient than traditional branch banking (Pikkarainen et al., 2004). In addition, this new banking system has significantly lower cost structure than traditional delivery channels. This delivery channel deserves special attention owing to its enormous potential from the viewpoint of banks, businesses and retail customers. Bank management have interest in studies which have investigated the adoption of $\mathbb{B}$ as the results can shed light on how to better market their Internet banking services and thus, accelerate the rate of adoption. If the service can more quickly reach a critical mass of customers (Rogers, 1995), the respective bank's investment in IB could be recouped more quickly.

Financial sector is the spinal cord of sovereign economy of any country. Iran is no exception. The technology adaptation in banking operations in Iran was a few decades behind that of in developed countries. In terms of international and global comparison, Internet usage in Iran is still relatively low and therefore onlinebanking is still in the infancy stage. Presently in Iran, an important function of e-commerce is the handling of payment over the Internet. Most e-commerce involves the exchange of some form of money for goods and services. Implementation of payment system for e-commerce is still evolving in Iran thus the number of proposal and implementation of payment system currently compete for dominant.

The literature review indicates the lack of non modelbased studies to date has sought to quantify of prominent demographic, behavioral and attitudinal characteristics as predictor of customer choice in the context of IB in Iran. To address this lacuna the present study was undertaken. The result could help bank managers to make informed decisions, thereby providing better services to their

Corresponding Author: Arezou Pour Mirza, Department of Industrial Engineering, Tarbiat Modares University, Tehran, Iran Department of Business Administration and Social Sciences, Luleå University of Technology, Luleå, Sweden Tel: +98912 2214487 
customers and formulate more efficacious strategies to ensure rapid migration of customers to IB.

Customer adoption: Consumers learn about goods and services by the development of experiences and the experiences are a major determinant of consumer choice and preferences (Foxall, 2003). It is revealed that not only banks customers use but also customers' acceptance supports and determines the success of Internet banking and this has a great influence on its adoption (Pikkarainen et al., 2004). As time passes, financial institutions world-wide become more interested in diversifying their traditional service delivery channels, basically the branch network, which is known to be associated with high staff and overhead costs. The advent of new channels has contributed not only to the adoption of multi-channel strategies by the existing institutions but also the emergence of new forms of financial businesses such as virtual banks. This trend is evident in the related literature that several studies have comparatively investigated the current usage levels and advantages of financial distribution channels (Akinçi et al., 2004). The advantages of Internet channels and especially the Internet over traditional branch banking were also underlined. Jayawardhena and Foley (2000) listed the advantages for banks: cost savings, increased customer base, mass customization, marketing and communication, innovation and development of noncore business. In the context of technologically based distribution channels, such as IB; customers' attitudes and motives have generally been significant for banks managers. If Iranian customers are not adopting IB services, it may be because they are not aware about such services being available and the benefit it offers. This concept leads us to different variables to be examined. The critical question is: What are the main effective factors that influence the adoption of retail IB services by Iranian customers?

To find an answer to this question, the past researches specifically paramount study of Lee et al. (2005) enabled us to extract the variables as well as personal and behavioral characteristics which have influence on adoption of IB services. Each of the identified measure will be stated in a set of variables to determine adopters' belief in adoption of the characteristic in question.

Mellat Bank from governmental sector is studied in this research because of its positive response in cooperating for conducting the research in bank. Mellat Bank has been established on April 1980 with a paid of capital of Rls $33.5 \mathrm{bn}$. Currently, the bank is one of the largest commercial banks in the Islamic Republic of Iran, ranking among the top 1000 banks of the world and one of the main governmental banks that have focused on electronic banking services, especially Internet banking (Economic focus, 2006, 2007).

The history of Internet banking: Innovative banking, since 1981 that was the introduction to the Automotive Teller Machines (ATMs), has grown aided mainly by technological developments in the telecommunications and information technology industry. Early 1990s was the time that Automated Voice Response (AVR) was introduced to the financial industry which gave the institutions the ability to launch telebanking services and facilities to their customers. As technology is revamping the ways that financial services are produced and delivered (Claessens et al., 2002); with these technological developments, by Intranet proprietary software, banks were able to offer services to customers who owned personal computers (Sohail and Shanmugham, 2003). NetBank in USA was the first online bank which was formed in 1996 under the name Atlanta Internet Bank and in 1997, second electronic bank; WingSpan was organized. Other online financial services such as Juniper.com, e-Trade.com entered the electronic banking environment in 2001 and well Established banks such as Citibank and Wells Fargo moved into this area of banking by offering such services to their existing customers in 2001 (Gefen and Straub, 2000). At recent years e-banking has experienced explosive growth and has transformed traditional practices in banking dramatically (Gonzalez et al., 2008).

Over the last 20 years, more of daily life activities are moved online in Iran and for this, electronic banking services can be important examples of this trend. The evolution of the electronic banking industry in Iran can be traced at late $70 \mathrm{~s}$. This was the time when two banks installed the first Automatic Teller Machines (ATM) in Tehran. Later; by the fast developments of technology in early 90 s the Iranian banks upgraded their automation standards and gradually, with the nationwide growth in Internet connectivity; fundamental platforms of online data transmission formed. At late $90 \mathrm{~s}$ a few of Iranian banks began to implement such services (Economic focus, 2007). Nowadays; technology runs through every part of the banking business in Iran. IB adoption in Iran is relatively low and very little research has been carried out to understand the key adoption determinants. In Iran IB is still new and in infancy stage and customers are less familiar and often more skeptical toward online banking transaction due to lack of knowledge and security.

Adoption is the acceptance and continued use of a product, service or idea. According to Rogers (1995), before customers can adopt an innovation they must learn about it, which this learning is called the adoption process and consists of awareness, interest, evaluation, trial and finally adoption. In general; customers will seek out, those financial products and suppliers which offer the best 
value for money and they are educated about it. Earlier studies suggest that customers' adoption of electronic banking technologies may be related to a number of factors, some associated with the characteristics of the product or service and others associated with the characteristics of the customers. For example, Gerrard and Cunningham (2003) used 41 statements to measure the characteristics related to the adoption of electronic banking and innovations by Singaporean customers. In another study in Singapore, Liao and Cheung (2002) found that individual expectations regarding accuracy, security, transaction speed, user-friendliness, user involvement and convenience were the most important quality attributes. Mattila et al. (2003) added that household income and education had a significant effect on the adoption of online banking among customers in Finland. Sathye (1999) identified security concerns and lack of awareness as the main obstacles to non-adoption of Australian customers.

Research variables: The expected relationship with regard to demographic, personal, behavioral and attitudinal characteristics can be outlined in the following variables. These variables will be examined in order to compare the adopters' and non-adopters' beliefs on the adoption of IB services. The variables were measured on the basis of the individuals' own self-assessment of how and why they perceive technology based financial services and their likelihood to use them. The variables are as followed:

- Variables related to demographic characteristics are; age, gender, marital status, educational level, occupation and household income

- Variables related to personal characteristics are; access to Internet, aim of Internet usage, delivery channel preference, lack of awareness from benefits, lack of technological skill, lack of security and trust

- Variables related to Internet banking usefulness are; transferring money within the same bank branches, transferring money to other banks, foreign exchanging and buying/selling stock, utility payments and getting information inquiry

- Variables related to IB characteristics are; convenient, less cost, security and privacy, ease of use, transaction speed, no need for carrying cash, suitable for any type of transaction, satisfy all the banking and financial transaction, easy usage by others and recommending to others

\section{MATERIALS AND METHODS}

Questionnaire: The questionnaire includes two sections. The first section gathers demographic information such as age, gender and etc. The second section has three parts. Part one asks customers about their personal information for their experience in using Internet and online banking. Part two asks the respondents attitudes about the usefulness of banking services and part three focuses on the respondents' satisfaction level about the IB services. The questionnaires were first pre-tested among 35 customers to comment on the relevance and wording of the questionnaire's items, length of survey and time taken to complete the questions and it was also reviewed carefully by professionals with extensive experience. The comments and suggestions of these professionals regarding the clarity, validity and consistency of the questions are incorporated into the survey instrument. Some of the questionnaire items were dropped, its layout was modified and the wording of some of the questionnaire was changed to improve the quality. Finally another test was carried out in one branch of the bank among 30 customers. The Cronbach's alpha value was calculated for these questionnaires and it was equal to 0.85 (over the recommended level of 0.70 ).

Sampling and data collection: Data collection was conducted from middle of September to the middle of November 2006, in four different branches of Mellat bank in Tehran. The population of interest is defined as two groups of Mellat bank's retail customers. Group one are those customers that have already adopted IB services (users) and group two are those who haven't adopted IB services (non-users). The method of sampling was random sampling. Total 500 questionnaires were distributed and each of responses received was screened for error, incomplete and missing responses. After the screening process was carried out 31 considered as unusable and totally 469 useable questionnaires were collected. These 469 respondents were later split to users and non users of IB services. This was done to know the reason why all the non users have not been using it and to know the problems that users were facing.

Data analysis techniques: Data reduction is implemented using factor analysis techniques and predicting the category of outcome for individual cases is achieved using logistic regression analysis (Norusis, 2008).

Development of the adoption characteristics: Factor analysis with varimax rotation is used to establish the dimensions appropriateness to model the adoption of IB services. Dimensions with eigenvalues of 1 or above are retained and different numbers of factors are emerged. Because the proposed approach involves criterion variables with two categories, for classification of variables, binomial logistic regression is implemented. 
Logistic regression analysis allows one to predict a discrete outcome from a set of variables that may be dichotomous, discrete, or a mix of any type of these. In this statistical technique the predictors do not have to be normally distributed, linearly related, or of equal variance within each group. The goal of logistic regression is to correctly predict the category of outcome for individual cases using the most parsimonious model. Since, most of the independent variables of this study are categorical, logistic regression is implemented.

\section{RESULTS}

The first six attributes are concerned with straightforward factual information. They are shown in Table 1, together with possible responses. The percentage value and significance level for each attribute are also listed. These are useful measures for depicting of tendency, towards the top or bottom of the scale. For instance; a percentage value of 22.77 for the age attribute means that there were more respondents from the middle age than the older and younger age groups. It can also be deduced from the table that in user group approximately $66 \%$ of respondents were male and $34 \%$ female. Also, concerning their occupational background, $59.78 \%$ of users were government's employees. Likewise, approximately $60 \%$ of the respondents were well educated. For more clarity, frequency, percentage and significance difference values of respondents on straightforward factual information is presented in Table 1.

The following five attributes are concerned with people's agreement or disagreement with a number of statements concerned with behavior and attitudes. The majority of the respondents $(53.02 \%)$ had access to Internet from office. Comparison of users and non-users proportions in this category revealed a significant difference between these two groups. Almost $65.83 \%$ of the respondents were using Internet for gathering information and news. An interesting piece of information was that, branch counter with $56.93 \%$ was the most preferred delivery channel of the customers. This finding indicated that the customers preferred traditional retail banking channel at present time. Concerning respondent awareness from benefits, results revealed significant difference among the means of the data and users were significantly more aware compared to non-user corresponding group. One of the main obstacles in online banking services usage was the lack of technical information specifically $\mathrm{PC}$ skills and a significant difference between users and non-users groups were observed. The most important obstacle in IB usage was the lack of trust to financial services security and a great deal of skepticism was detected among the customers. In this context approximately $42 \%$ of respondents were worried and a significant difference between users and

Table 1: Straightforward factual information

\begin{tabular}{|c|c|c|c|c|c|c|}
\hline \multirow[b]{2}{*}{ Variables } & \multirow[b]{2}{*}{ Classification of variables } & \multicolumn{2}{|l|}{ Users } & \multicolumn{2}{|l|}{ Non-users } & \multirow{2}{*}{$\begin{array}{l}\text { Significance } \\
\text { of difference }\end{array}$} \\
\hline & & Frequency & Percentage & Frequency & Percentage & \\
\hline \multirow[t]{7}{*}{ Age } & $20-25$ & 28 & 9.96 & 21 & 11.18 & $0.377^{\text {ns }}$ \\
\hline & $26-30$ & 62 & 22.06 & 41 & 21.81 & $0.476^{\text {ns }}$ \\
\hline & $31-35$ & 64 & 22.77 & 47 & 25.00 & $0.287^{\mathrm{ns}}$ \\
\hline & $36-40$ & 55 & 19.57 & 27 & 14.36 & $0.072^{\text {ns }}$ \\
\hline & $41-45$ & 31 & 11.03 & 29 & 15.42 & $0.082^{\text {ns }}$ \\
\hline & $46-50$ & 25 & 8.91 & 12 & 6.38 & $0.158^{\text {ns }}$ \\
\hline & $\geq 51$ & 16 & 5.70 & 11 & 5.85 & $0.232^{\mathrm{ns}}$ \\
\hline \multirow[t]{2}{*}{ Gender } & Male & 185 & 65.83 & 152 & 80.85 & $0.010^{* * *}$ \\
\hline & Female & 96 & 34.17 & 36 & 19.15 & $0.000^{* * *}$ \\
\hline \multirow[t]{2}{*}{ Marital status } & Single & 77 & 27.40 & 33 & 17.55 & $0.000^{*}$ \\
\hline & Married & 204 & 72.60 & 155 & 82.44 & $0.000^{*}$ \\
\hline \multirow[t]{6}{*}{ Educational level } & Under secondary & 6 & 2.14 & 27 & 14.37 & $0.000^{*}$ \\
\hline & Diploma & 55 & 19.57 & 57 & 30.32 & $0.003^{*}$ \\
\hline & Junior college & 54 & 19.22 & 52 & 27.66 & $0.017^{*}$ \\
\hline & Bachelors degree & 105 & 37.36 & 44 & 23.40 & $0.000^{*}$ \\
\hline & Masters degree & 53 & 18.86 & 6 & 3.19 & $0.000^{*}$ \\
\hline & Ph.Ds & 8 & 2.85 & 2 & 1.06 & $0.091^{\text {ns }}$ \\
\hline \multirow[t]{4}{*}{ Occupation } & Governmental & 168 & 59.78 & 48 & 25.54 & $0.000^{* * *}$ \\
\hline & Private & 29 & 10.32 & 37 & 19.68 & $0.002^{*}$ \\
\hline & Self-employment & 47 & 16.72 & 76 & 40.42 & $0.000^{*}$ \\
\hline & Other & 37 & 13.16 & 27 & 14.36 & $0.360^{n s}$ \\
\hline \multirow[t]{6}{*}{ Income (Rials) } & $0-2000000$ & 44 & 15.66 & 28 & 14.90 & $0.409^{\text {ns }}$ \\
\hline & $2,010,000-4,000,000$ & 64 & 22.77 & 46 & 24.47 & $0.308^{\text {ns }}$ \\
\hline & $4,010,000-6,000,000$ & 91 & 32.38 & 66 & 35.10 & $0.267^{\text {ns }}$ \\
\hline & $6,010,000-8,000,000$ & 54 & 19.22 & 31 & 16.49 & $0.223^{\text {ns }}$ \\
\hline & $8,010,000-10,000,000$ & 20 & 7.12 & 11 & 5.85 & $0.000^{*}$ \\
\hline & $\geq 10^{\prime} 100^{\prime} 000$ & 8 & 2.85 & 6 & 3.19 & $0.416^{\text {ns }}$ \\
\hline
\end{tabular}

**Significant at the $1 \%$ level of probability; ${ }^{*}$ Significant at the $5 \%$ level of probability; ${ }^{\text {ns: Not Significant }}$ 
non-users groups was appeared and user respondents were more security concerned than non-users group.

For variables related to IB usefulness, the research variables i.e., information inquiry, transferring money within the same bank branches, transferring money to other banks, foreign exchanging and buying/selling stock and utility payment were subjected to the principal component analysis (correlation matrix approach) using orthogonal rotation, specifically varimax rotation. Also the $\mathrm{KMO}$ and Bartlett's sphericity was used to test the sample appropriateness. The variables, which had loadings of less than 0.5 , were excluded and dimensions with eigenvalues of 1 or above; were retained.

Table 2 exhibits the correlation matrix of all the variables and it shows that all variables were correlated well and there is no need to eliminate any variable. Also, the large values of Bartlett's sphericity test (569.7, $\mathrm{df}=10$, $\mathrm{p}=0.000$ ) and $\mathrm{KMO}$ statistics (0.83) indicated the appropriateness of factor analysis i.e., the sample was adequate. Moreover, determinant was used to test for multicollinearity and since it was 0.128 and was greater than 0.00001 ; multicollinearity was not a problem for the data. Similarly; Cooper and Schindler (2003) argued that while the correlation coefficients in matrix table are less than 0.80 , the multicollinearity could be ignored.

Table 3 shows only 1 factor that was extracted from the analysis along with its eigenvalues, the percentage of variance attributed to the factor $(61.806 \%)$ and also exhibits the cumulative variance of the factor. Since, only one component was extracted; the solution could not be rotated. From the user respondents' point of view, the five attributes could be viewed as only one and is meant that IB services had great influence on making the financial and banking transactions quick with more compatibility and convenience.

For logistic regression analysis, first all 5 variables were entered into the general model and subsequently a backward stepwise method regression was employed. The backward stepwise model was same as the general model. However, due to reduction in multicollinearity, the significance of the variables increased. Of the 5 variables entered, information inquiry, balance statement and credit card statement, was found to be significant at 5\% level. Table 4 presents the logistic regression analysis results with a significant effect on the adoption of IB along with all related statistics. Based on the $\beta$ values; it appears that two variables have a positive effect on the odds of a person belonging to the IB users, whereas three variables have a negative effect.

The general model correctly classified $68.3 \%$ of cases, which means it was a good predictor in $68.3 \%$ of the cases in differentiating the users from non-users of IB services. In the second stage, the factor that was found to be significant in the general model was again significant in this stage. This factor was information inquiry for balance statements and credit card statements. The logistic regression analysis for both general and backward stepwise method regression models showed that information inquiry as one of the Internet banking

Table 2: Correlation matrix result

\begin{tabular}{|c|c|c|c|c|c|}
\hline Variables & $\begin{array}{l}\text { Information } \\
\text { inquiry }\end{array}$ & $\begin{array}{l}\text { Transferring money within } \\
\text { the same bank branches }\end{array}$ & $\begin{array}{l}\text { Transferring money } \\
\text { to other banks }\end{array}$ & $\begin{array}{l}\text { Foreign exchanging } \\
\text { and buy ing/selling stock }\end{array}$ & $\begin{array}{l}\text { Utility } \\
\text { payment }\end{array}$ \\
\hline Information inquiry & 1.00 & & & & \\
\hline $\begin{array}{l}\text { Transferring money within } \\
\text { the same bank branches }\end{array}$ & 0.498 & 1.00 & & & \\
\hline Transferring money to other banks & 0.389 & 0.706 & 1.00 & & \\
\hline Foreign exchanging and buy ing/selling stock & 0.396 & 0.534 & 0.565 & 1.00 & \\
\hline Utility payment & 0.387 & 0.566 & 0.638 & 0.492 & 1.00 \\
\hline
\end{tabular}

Table 3: Total variance explained

\begin{tabular}{lccccc}
\hline & Initial eigenvalues & & & Extraction sums of squared loadings \\
Component & Total & Variance (\%) & Cumulative (\%) & Total & Variance (\%) \\
\hline 1 & 3.090 & 61.806 & 61.806 & 3.090 \\
2 & 0.687 & 13.750 & 75.556 & 61.806 \\
3 & 0.522 & 10.443 & 85.999 & \\
4 & 0.433 & 8.666 & 94.665 & \\
5 & 0.267 & 5.335 & 100.000 & \\
\hline
\end{tabular}

Table 4: Results of logistic regression analysis

\begin{tabular}{|c|c|c|c|c|c|c|}
\hline Variables & $\mathrm{B}$ & SE & Wald & df & Sig. & $\operatorname{Exp}(\mathrm{B})$ \\
\hline Information inquiry & 0.380 & 0.164 & 5.396 & 1 & $0.020^{*}$ & 1.462 \\
\hline Transferring money within the same bank branches & 0.247 & 0.179 & 1.898 & 1 & $0.168^{\text {ns }}$ & 1.280 \\
\hline Transferring money to other banks & -0.185 & 0.162 & 1.298 & 1 & $0.255^{\text {ns }}$ & 0.831 \\
\hline Foreign exchanging and buy ing/selling stock & -0.048 & 0.111 & 0.186 & 1 & $0.666^{\text {ns }}$ & 0.953 \\
\hline Utility payment & -0.145 & 0.162 & 0.794 & 1 & $0.373^{\text {ns }}$ & 0.865 \\
\hline
\end{tabular}




\begin{tabular}{|c|c|c|c|c|c|c|c|c|c|c|c|c|c|}
\hline \multicolumn{3}{|l|}{ Variables } & \multirow{2}{*}{$\begin{array}{c}\text { Convenient } \\
1.000\end{array}$} & \multirow[t]{2}{*}{ Cost } & $\begin{array}{l}\text { Security } \\
\text { and } \\
\text { privacy }\end{array}$ & $\begin{array}{l}\text { Ease } \\
\text { of use }\end{array}$ & $\begin{array}{l}\text { Quick } \\
\text { transaction }\end{array}$ & $\begin{array}{l}\text { No need } \\
\text { for carrying } \\
\text { cash }\end{array}$ & $\begin{array}{l}\text { Suitable for } \\
\text { any banking } \\
\text { and transaction }\end{array}$ & \multicolumn{2}{|c|}{$\begin{array}{l}\text { Satisfy all } \\
\text { banking and } \\
\text { financial needs }\end{array}$} & \multirow[t]{2}{*}{$\begin{array}{l}\text { Easy } \\
\text { usage } \\
\text { of others }\end{array}$} & $\begin{array}{l}\text { Recommending } \\
\text { to others }\end{array}$ \\
\hline \multicolumn{3}{|l|}{ Convenient } & & & & & & & & & & & \\
\hline \multicolumn{3}{|l|}{ Cost } & 0.281 & 1.000 & & & & & & & & & \\
\hline \multicolumn{3}{|c|}{ Security and privacy } & 0.101 & 0.556 & 1.000 & & & & & & & & \\
\hline \multicolumn{3}{|c|}{ Ease of use } & 0.111 & 0.483 & 0.595 & 1.000 & & & & & & & \\
\hline \multicolumn{3}{|c|}{ Quick transaction } & 0.025 & 0.365 & 0.429 & 0.653 & 1.000 & & & & & & \\
\hline \multicolumn{3}{|c|}{ No need for carrying cash } & 0.146 & 0.381 & 0.277 & 0.369 & 0.257 & 1.000 & & & & & \\
\hline \multicolumn{3}{|c|}{ Suitable for any banking and transaction } & 0.141 & 0.361 & 0.446 & 0.525 & 0.424 & 0.463 & 1.000 & \multirow{2}{*}{\multicolumn{2}{|c|}{1.000}} & & \\
\hline \multicolumn{3}{|c|}{ Satisfy all banking and financial needs } & -0.100 & 0.195 & 0.321 & 0.444 & 0.470 & 0.110 & 0.363 & & & & \\
\hline Easy usage of & hers & & -0.012 & 0.253 & 0.412 & 0.409 & 0.447 & 0.237 & 0.420 & \multirow{2}{*}{\multicolumn{2}{|c|}{$\begin{array}{l}0.397 \\
0.307 \\
\end{array}$}} & 1.00 & \\
\hline \multicolumn{3}{|c|}{ Recommending to others } & 0.141 & 0.260 & 0.390 & 0.462 & 0.447 & 0.263 & 0.419 & & & 0.678 & 1.000 \\
\hline \multicolumn{14}{|c|}{ Table 6: Total variance explained } \\
\hline \multirow[b]{2}{*}{ Component } & \multicolumn{4}{|c|}{ Initial eigenvalues } & \multicolumn{5}{|c|}{ Extraction sums of squared loadings } & \multicolumn{4}{|c|}{ Rotation sums of squared loadings } \\
\hline & Total & Variance $(\%)$ & \multicolumn{2}{|c|}{ Cumulative (\%) } & \multicolumn{2}{|c|}{ Total } & Variance $(\%$ & \multicolumn{2}{|c|}{ Cumulative (\%) } & Total & Varia & ince (\%) & Cumulative (\%) \\
\hline 1 & 4.257 & 42.569 & 42.5 & & 4.25 & & 42.569 & 42. & 569 & 3.492 & & 918 & 34.918 \\
\hline 2 & 1.325 & 13.249 & 55.8 & & 1.32 & & 13.249 & & 818 & 2.090 & & 899 & 55.818 \\
\hline 3 & .918 & 9.183 & 65.0 & & & & & & & & & & \\
\hline 4 & .827 & 8.270 & 73.2 & & & & & & & & & & \\
\hline 5 & .685 & 6.852 & 80.1 & & & & & & & & & & \\
\hline 6 & .550 & 5.502 & 85.6 & & & & & & & & & & \\
\hline 7 & .486 & 4.865 & 90.4 & & & & & & & & & & \\
\hline 8 & .377 & 3.771 & 94.2 & & & & & & & & & & \\
\hline 9 & .310 & 3.099 & 97.3 & & & & & & & & & & \\
\hline 10 & .264 & 2.641 & 100.0 & & & & & & & & & & \\
\hline
\end{tabular}

services was an important factor in the adoption process rather than other banking services.

The remaining 10 attributes are concerned with people's agreement or disagreement with a number of statements concerned with behavior and attitudes. Table 5 shows the correlation matrix of all the variables related to IB characteristics and it presents that all variables correlated well and none of the correlation coefficient is exceptionally large, therefore, there is no need to eliminate any variable. Also, the large values of Bartlett's sphericity test $(1026, \mathrm{df}=45, \mathrm{p}=0.000)$ and $\mathrm{KMO}(0.84)$ indicate the appropriateness of factor analysis i.e., the sample is adequate. The determinant is used to test for multicollinearity and since it is .024 and greater than 0.00001 , multicollinearity is not a problem for the data.

To identify the major respondent segments among IB users, the data of relevant attributes were subjected to factor analysis. Dimensions with eigenvalues of 1 or above were retained and as shown in Table 6 , two factors emerged. The variables were as followed: convenient, cost, security and privacy, easy to use, speed transaction, no need for carrying cash, more suitable, satisfy transaction, easy usage of others and recommend to others. Table 6 exhibits all the factors extractable from the analysis along with their eigenvalues, the percentage of variance attributed to each factor and also shows the cumulative variance of the factors and the earlier factors.
In the final part of this table, the eigenvalues of the factors after rotation are displayed and thus has the effect of optimizing the factor structure and one consequence for these data is that the relative importance of the two factors is equalized. Before rotation, factor 1 account for considerably more variance than the other $(42.56 \%$ compared to $13.24 \%$ ). However, after extraction, it account for only $34.9 \%$ of variance compared to $20.89 \%$, respectively.

Table 7 shows the component matrix before rotation and all the loadings less than 0.6 are suppressed in the output so there are blank spaces for many of the loadings less than 0.6 . It can be observed from this table that cost, security and privacy, easy to use, speed transaction, more suitable, easy usage of others and recommend to others load on factor 1 and only convenient load on factor 2 .

In the rotated factor matrix of Table 8 , component 1 has high coefficients for security and privacy, ease of use, quick transaction, suitable for any banking and financial transactions, satisfying all banking and financial needs, easy usage of others and recommending to others. Therefore, this component may be labeled as, availability and easy usage of financial and banking transactions. Component 2 is highly related with convenience, low/no cost and no need for carrying cash. Thus, component 2 may be labeled as, flexibility of banking transactions. One could summarize the data by stating that customers 
Table 7: Component matrix

\begin{tabular}{lll}
\hline & Component \\
\hline Variables & 1 & 2 \\
\hline Convenient & 0.0 & 0.723 \\
Cost & 0.629 & \\
Security and privacy & 0.730 & \\
Ease of use & 0.820 & \\
Quick transaction & 0.740 & \\
No need for carrying cash suitable for any & 0.722 & \\
banking and transaction & & \\
Satisfy all banking and financial needs easy & 0.690 & \\
usage of others & & \\
Recommending to others & 0.695 & \\
\hline
\end{tabular}

Table 8: Rotated component matrix

\begin{tabular}{lll}
\hline & Component & \\
\cline { 2 - 3 } Variables & 1 & 2 \\
\hline Convenient & & 0.711 \\
Cost & & 0.722 \\
Security and privacy & 0.703 & \\
$\begin{array}{l}\text { Ease of use } \\
\text { Quick transaction }\end{array}$ & 0.744 & \\
No need for carrying cash & & \\
Suitable for any banking and transaction & & \\
Satisfy all banking and financial needs & 0.730 & \\
Easy usage of others & 0.765 & \\
Recommending to others & 0.686 & \\
\hline
\end{tabular}

Table 9: Results of logistic regression analysis

\begin{tabular}{lrlllll}
\hline Variables & $\mathrm{B}$ & $\mathrm{SE}$ & Wald & df & Sig. & Exp (B) \\
\hline Convenient & 0.209 & 0.083 & 6.355 & 1 & $0.012^{*}$ & 1.233 \\
Cost & -0.095 & 0.152 & 0.393 & 1 & $0.531^{\text {ns }}$ & 0.909 \\
Security and privacy & 0.169 & 0.137 & 1.523 & 1 & $0.217^{\text {ns }}$ & 1.184 \\
Easy to use & 0.170 & 0.164 & 1.075 & 1 & $0.300^{\text {ns }}$ & 1.185 \\
Speed transaction & -0.228 & 0.135 & 2.859 & 1 & $0.091^{\text {ns }}$ & 0.796 \\
No need for carrying cash & 0.441 & 0.183 & 5.842 & 1 & $0.016^{*}$ & 1.555 \\
More suitable & 0.309 & 0.156 & 3.917 & 1 & $0.048^{*}$ & 1.362 \\
Satisfy transaction & -0.229 & 0.103 & 4.952 & 1 & $0.026^{*}$ & 0.795 \\
Easy usage of others & -0.035 & 0.120 & 0.084 & 1 & $0.772^{\text {ns }}$ & 0.966 \\
Recommend to others & -0.061 & 0.131 & 0.216 & 1 & $0.642^{\text {ns }}$ & 0.941 \\
\hline
\end{tabular}

appear to seek two major kinds of benefits from satisfaction of IB services: First; availability and easy usage of financial and banking transactions and second; flexibility of banking transactions.

In subsequent data analysis, logistic regression analysis was carried out. Table 9 exhibits the logit model of the factors with a significant effect on the adoption of IB. Based on the $\beta$ values it appears that five variables have a positive effect on the odds of a customer belonging to the IB users, whereas other five variables have a negative effect. While customers who perceive more secure and convenience in Internet banking and its rather straightforward use have significantly higher odds to actually adopt IB. In performing logistic regression analysis, first all 10 variables were entered into the general model and secondly a backward stepwise method regression was carried out. Of the 10 variables entered, 4 were found to be significant at $5 \%$ level. The significant factors were convenience, no need for cash, usefulness and satisfaction.
The general model correctly classified $71.2 \%$ of cases, which means it was a good predictor in $71 \%$ of the cases in differentiating the users from non-users. To simplify the model, the regression backward method was conducted with all 10 variables. All the factors that were found to be significant in the general model were again significant in this stage. The model correctly classified $71.5 \%$ of the cases. The logistic regression analysis for both general and backward stepwise method regression models showed that convenience, no need for carrying cash, usefulness and satisfaction were more important factors in the adoption process of IB services rather than other IB characteristics.

\section{DISCUSSION}

Several scholars have analyzed mainly the demographic characteristics of IB customers but lesser emphasis has been placed on analyzing behavioral, attidunial and social characteristics of the bank clients. The empirical findings of the current study show that these characteristics have effective impacts on adoption of IB services. In terms of personal and social characteristics, this study contributes to this purpose, by identifying the Iranian customer's attitude toward IB services. Among demographic characteristics, more significant influence is found for gender, educational level and monthly income. Gender has not been found to have a direct effect on adoption of technology in general (Gefen and Straub, 2000), whereas the results of current study reveals that males represent the segment with the highest use of IB services. This finding is in agreement with the results of Faith et al. (2007), who argue that gender could affect the intention to adopt e-commerce including online banking. Besides, higher use of IB has been evident for those who have higher educational level. Also, a similar trend of IB usage is detected to those customers with middle-class income. With notice to the large number of customers belonging to this class of monthly income, if the bank's manager strategy approaches towards these customers, by providing special offers, it may be successful to help increase the adoption rate of IB services. Therefore, bank managers should focus their promotion activities aimed at such customers.

The majority of the customers are very comfortable and willing to use IB services. Hence, it is very important for Iranian banks to have online banking services. It is well-accepted fact that; providing good customer service and convincing the customers about the non-economic relative advantages such as easy and safe payment and protecting from theft or losing of cash, will increase the number of adopters after a while. Based on the results, 
negative perceptions of the Internet banking services such as risk of safety and risk of error have detrimental impacts on adoption. So, bank managers should focus their promotional activities, aimed to counteract such negative perceptions. The finding about the impact of age on adoption of online banking services indicates that the effect of age is not prominent. Therefore, age is not a crucial variable for banks that are planning to offer IB services. In comparative terms; lack of trust to financial services security was not rated differentially. Gefen and Straub (2003) argue that trust is a crucial factor in many transaction relationships.

Generally, customers do not trust e-banking for some reasons especially due to lack of the security of the system (Rotchanakitumnuai and Speece, 2003). The results of current study revealed that all the customers are very concerned about security in transaction processes. This result is in consistent with the results, which have been reported earlier by other scholars (Black et al., 2001; Lee and Turban, 2001; Polatoglü and Ekin, 2001; Shah Alam et al., 2007). Thus, in order to lure non-users respondents into IB user group, bank manager needs to explain the high level of security, which supports the bank's computer system from third-party intrusions into an Internet account. Another issue, which should be considered, is unequal level of PC skill between users and non-users customers. PC proficiency has significant influence on adoption. Hence, mass adoption and widespread diffusion of IB will only occur when such technological barrier is lowered. People with higher PC self-efficacy are more readily prepared to use online banking services. Since there is a great number of Iranian who has no IB account at present, the potential for IB in Iran is high. To achieve these outcomes, the study identifies a number of strategies which bank managers could follow. While this study is a maiden attempt in this aspect in Iran; the result could be served as a baseline data for further research and future researches can hopefully look for further avenues in exploring the areas.

\section{CONCLUSION AND LIMITATION}

The majority of the customers are very comfortable and willing to use IB services. This is an important issue for Iranian banks to have high quality online banking services. Out of many factors that have been tested to be influencing the adoption of IB in Iran, four factors have been identified as more significant factors. The analysis shows that security concerns and lack of awareness stand out as the reasons for non-adoption of IB services by Iranian customers. These are the main reasons for not opening online banking or investment accounts. Thus, in order to lure non-users respondents into IB user group, bank manager needs to explain the high level of security, which supports the bank's computer system from thirdparty intrusions into an Internet account. Among demographic variables; further significant influences have been found for gender and the type of occupation. In this context, the higher rate of using Internet banking services has been found for government employees. Regarding the large number of governmental organizations in Iran, if banks provide special offers for this segment, it may be successful to help increase the adoption rate of IB. This measure could help in rapid migration of customers to IB, resulting in considerable saving in operating costs for banks.

The key contribution of this study is the identification of prominent demographic, behavioral and attitudinal characteristics as predictor of customer choice in the context of IB services in Iran. This could ultimately lead to enhanced abilities for bank managers to develop more secure and trustable products. Also, this study sets an important benchmark for further research in the area.

Since, the sample size is limited; the findings can be taken only as indicative results and the findings have to be compared and confirmed with a research with much bigger sample size to obtain better accuracy. Some of the respondents do not know much about Internet banking and thereby rejected the questionnaire.

\section{ACKNOWLEDGMENT}

The authors are grateful to Tarbiat Modares University (TMU) and Luleå University of Technology (LTU) for financial support and research facilities. The grant No. is 403709.

\section{REFERENCES}

Akinçi, S., S. Aksoy and E. Atilgan, 2004. Adoption of Internet banking among sophisticated customer segments in an advanced developing country. Int. J. Bank Market., 22: 212-232.

Black, N.J., A. Lokett, H. Winklhofer and C. Ennew, 2001. The adoption of Internet financial services: A qualitative study. Int. J. Retail Distribut. Manage., 29: 390-398.

Brodie, R.J., H. Winklhofer, N.E. Coviello and W.J. Johnston, 2007. Is e-marketing coming of age? An examination of the penetration of e-marketing and firm performance. J. Interac. Market., 21: 2-21.

Claessens, S., T. Glaessner and D. Klingebiel, 2002. Electronic finance: Reshaping the financial landscape around the world. J. Finance. Serv. Res., 22: 29-61.

Cooper, D.R. and P.S. Schindler, 2003. Business Research Methods. MacGraw-Hill, New York. 
David, H., N. Wong Rexha and I. Phau, 2008. Reexamining traditional service quality in an e-banking era. Int. J. Bank Market., 26: 526-545.

Economic Focus, 2006. Iran Daily Newspaper. http://irandaily.com/1385/2742/html/focus.htm.

Economic Focus, 2007. Iran Daily Newspaper. http://irandaily.com/1385/2770/html/focus.htm.

Faith, M., E. Uzoka, G. Geoffrey Seleka and J. Khengere, 2007. E-commerce adoption in developing countries: A case analysis of environmental and organizational inhibitors. Int. J. Inform. Syst. Change Manage., 2: $232-260$.

Foxall, K., 2003. The behavior analysis of consumer choice: An introduction to special issue. J. Econ. Psychol., 24: 581-588.

Gefen, D. and D. Straub, 2000. The relative importance of perceived ease of use in IS adoption: A study of E-Commerce adoption. J. Assoc. Inform. Syst., 1: $1-28$.

Gefen, D. and D. Straub, 2003. Managing user trust in B2C e-services. E-Serv. J., 2: 7-24.

Gerrard, P. and J.B. Cunningham, 2003. The diffusion of Internet banking among Singapore. Int. J. Bank Market., 21: 16-28.

Gonzalez, M.E., M.R. Dentiste and M.W. Rhonda, 2008. An alternative approach in service quality: An e-banking case study. Qual. Manage. J., 15: 41-48.

Jayawardhena, C. and P. Foley, 2000. Changes in the banking sector: The case of Internet banking in the UK. Internet Res. Elect. Network. Appl. Policy, 10: $19-30$.

Lee, E.J., K.N. Kwon and D.W. Schumann, 2005. Segmentation the non-adopter category in the diffusion of Internet banking. Int. J. Bank Market., 33: $414-437$.
Lee, M.K.O. and E. Turban, 2001. A trust model for consumer Internet shopping. Int. J. Elect. Com., 6: 75-91.

Liao, Z. and M.T. Cheung, 2002. Internet-based e-banking and consumer attitudes: An empirical study, Infom. Manage., 39: 283-295.

Mattila, M., H. Karjaluoto and T. Pento, 2003. Internet banking adoption among mature customers: Early majority or laggards. J. Serv. Market., 17: 514-528.

Norusis, M.J., 2008. SPSS 16.0 Guide to Data Analysis. Prentice Hall, Upper Saddle River, Nigeria, ISBN-13: 9780136061366.

Pikkarainen, T., K. Pikkarranien, H. Karjaluoto and S. Pahnila, 2004. Customer acceptance of online banking: An extension of the technology acceptance mode. Int. Res., 14: 224-235.

Polatoglü, V.N. and S. Ekin, 2001. An empirical investigation of the Turkish consumers acceptance of Internet banking services. Int. J. Bank Market., 19: $156-165$.

Rogers, E.M., 1995. Diffusion of Innovation. 4th Edn., The Free Press, New York, ISBN: 0029266718.

Rotchanakitumnuai, S. and M. Speece, 2003. Barriers to Internet banking adoption: A qualitative study among corporate customers in Thailand. Int. J. Bank Market., 21: 312-323.

Sathye, M., 1999. Adoption of Internet banking by Australian consumers: An empirical investigation. Int. J. Bank Market., 17: 324-334.

Shah Alam, S., A. Khatibi and M.I. Sayyed Ahmad, 2007. Factors affecting e-commerce in the electronic manufacturing companies in Malaysia. Int. J. Com. Manage., 17: 125-129.

Sohail, M.S. and B. Shanmugham, 2003. E-banking and customer preferences in Malaysia: An empirical investigation. Inform. Sci., 150: 207-217. 